\title{
ALTERATIONS OF DNA METHYLATION IN DIVERSE GRAFTED HYBRID TOMATOES (Solanum lycopersicum L.)
}

\author{
Xu Xincheng ${ }^{1}$, Zulfiqar Ali ${ }^{2,3, *}$, Song Weiyi ${ }^{1}$, Nida Ghori ${ }^{2}$, Shao Hongbo ${ }^{4,5, *}$ and Ding Jinping ${ }^{1}$ \\ ${ }^{1}$ Department of Life Science, Shangqiu Normal University, Shangqiu 476000, China; ${ }^{2}$ Department of Plant Breeding \\ and Genetics, University of Agriculture, Faisalabad, Pakistan; ${ }^{3}$ Department of Plant Breeding and Genetics, MNS \\ University of Agriculture, Multan, Pakistan; ${ }^{4}$ Institute of Agro-biotechnology, Jiangsu Academy of Agricultural \\ Sciences, Nanjing 210014, China; ${ }^{5}$ Key Laboratory of Coastal Biology and Bioresources Utilization, Yantai Institute \\ of Coastal Zone Research (YIC), Chinese Academy of Sciences (CAS), Yantai 264003, China. \\ "Corresponding author's e-mail: hbshao@yic.ac.cn; zulfiqarpbg@ hotmail.com
}

\begin{abstract}
Tomato is an edible and useful vegetable. Navel rot disease and low light stress are the problem in tomato cultivation. Tomato breeding is a potential cheap solution but takes longer time. Grafting technology provides instant solution like cultivating sensitive tomato (scion) grafted on resistant rootstock on non-optimal environmental conditions. DNA methylation of grafted plants might help to adapt to the adverse conditions and has become a hot point in researches concerning vegetable breeding. In this research, disease-resistant tomato cultivar " 1221 " was used as rootstock, while disease-sensitive tomato cultivar "Money Maker (MM)" was used as scion. After grafting, changes of genomic global DNA methylation were investigated through MSAP analysis. According to MSAP analysis, alterations of degree of DNA methylation patterns were observed, which might help graft hybrids to adapt in response to the internal and external stimuli.

Keywords: MSAP analysis, restriction digestion, PCR, PAGE, silver staining
\end{abstract}

\section{INTRODUCTION}

Tomato (Solanum lycopersicum L.) is the most widely cultivated and used edible vegetable, and has generated huge economic benefits (Ahmad et al., 2014; Saleem et al., 2015). It is useful for stomach invigoration, blood pressure reduction, diuresis, anti-inflammation and detoxification. It is abundant in vitamin $\mathrm{A}$, vitamin $\mathrm{C}$, carotene, and lycopene, which are beneficial for the prevention of vascular aging. In addition, it is also rich in anti-oxidants, anti-aging and antiwrinkle agents (Riggi et al., 2008). Its cultivation on largescale faces differences in soil conditions, biotic and abiotic stresses. Among biotic stresses, navel rot disease poses serious threat to tomato production and causes huge economic loss (Patene et al., 2011; Kuscu et al., 2014), while low light stress is a problem in greenhouse cultivation

Applying traditional insecticide/fungicide preventions can't fundamentally address the issue of pest and disease occurrence during the process of tomato production. Tomato breeding has potential and provides one of the cheap solutions to address the soil borne diseases. However, breeding disease tolerant tomato cultivars needs several years. Whereas grafting technology enable cultivation of sensitive tomato (scion) grafted on resistant rootstock under non-optimal environmental conditions in short span (Ding et al., 2015). Therefore, grafting represents one of the best solutions for cultivating tomato cultivars with good agronomic traits such as weak light-tolerance and aerial adversity resistance as scion using soil adversity resistant root stock.

Epigenetic phenomena refer to the regulation of alterations of gene expression without the alteration of DNA sequences (Davies et al., 1997; Ozbahce and Tari, 2010). DNA methylation represents one of the main approaches for the modification of eukaryotic DNA playing vital roles in regulating gene expression and maintaining gene stability. It was found in many researches that the alterations of cellular environment can readily cause changes in DNA methylation leading to the variations of biological traits of organisms. In higher plants, cellular DNA methylation primarily exists in the form of 5-methylcytosine, which represents a kind of relatively conservative genetic mark. Such inheritable epigenetic modifications as cellular DNA methylations frequently lead to physiological and biochemical changes in responses of plants under non-optimal environments (Davies et al., 1997; Ozbahce and Tari, 2010). Currently, many studies have shown close relationships between epigenetic phenomena and plants' resistances to adverse stresses (Hanson and May 2006; Benard et al., 2009; Flores et al., 2010; Yu and Ong, 2003; Rahmatian et al., 2014; Lazár et al., 2006; Stitt and Usadel, 2010).

In this research, disease-resistant tomato cultivar " 1221 " was used as rootstock, while disease-sensitive tomato cultivar "Money Maker" (MM) was grafted as scion, which was weak-light stress tolerant. After grafting, variations in genomic global DNA methylation were investigated and presented in this paper. 


\section{MATERIALS AND METHODS}

Plant material, seedling growth and grafting conditions: A combination of graft was selected, disease-sensitive tomato cultivar "Money Maker" (MM) was grafted as scion on disease-resistant rootstock of tomato cultivar "1221" (Ding et al., 2015). MM is weak-light stress resistant (Qi and $\mathrm{Li}$, 2011). Seeds of testing cultivars were planted into $15 \mathrm{~cm}$ wide and $10 \mathrm{~cm}$ deep perforated nutrition bowls containing $300 \mathrm{~g}$ of sand as growth matrix. The bowls were placed in the growth chamber set at $20 / 25 \pm 2^{\circ} \mathrm{C}$ night/day temperature, $12 \mathrm{~h}$ photoperiod, $70 \%$ humidity and 4000 lux light intensity. After germination, the seedlings were irrigated with $200 \mathrm{ml} \mathrm{1/2}$ strength Hoagland's nutritional solution once a week while $200 \mathrm{ml}$ tap-water was applied daily. Grafting was conducted through the adoption of cleft graft (Wu et al., 2010). At grafting, the seedlings were disinfected with spraying of $5 \%$ sodium hypochlorite, covered with freezer (polythene) bags, and placed at cool places for further growth. After a week, freezer bags were removed and normal cultivation of 50 grafted seedlings along with six seedlings of each control variety (CK, un-grafted "1221" and "MM") was conducted.

Total DNA extraction: Total DNA of tomato seedlings was extracted from randomly sampled $0.5 \mathrm{~g}$ leaves at 3-leaf stage according to the methods described by Cao et al. (2003).

Analysis on methylation sensitive amplification polymorphism (MSAP): MSAP technology employs two kinds of isoschizomers for restriction digestion, namely Msp I and Hpa II, which differ in their degrees of sensitivity to methylation sites. The procedure of this analysis includes such steps as double enzyme digestion of genomic DNA, connection of artificial adaptors, pre-amplification, selective amplification, PAGE electrophoresis, and band analysis (Chen and Pikaard, 1997; Davies et al., 1997).

Restrictive enzymatic digestion and connection of artificial adaptors: Before restrictive enzymatic digestion and connection, single-stranded adaptors were annealed to double-stranded structures (under $72^{\circ} \mathrm{C}$ treatment for $5 \mathrm{~min}$ ), slowly cooled to room temperature, and finally stored in $-20^{\circ} \mathrm{C}$ freezer for further usages. The reactive solution was evenly mixed as $0.1 \mu \mathrm{L}$ BSA $(10 \mathrm{mg} / \mathrm{L}), 2.0 \mu \mathrm{L}$ T4 $10 \times$ reaction buffer, $0.5 \mu \mathrm{L}$ EcoR I adaptor (5 pM), $0.5 \mu \mathrm{L}$ EcoR (20 $\mathrm{U} / \mu \mathrm{L}), 0.5 \mu \mathrm{L} \mathrm{H} / \mathrm{M}$ adaptor $(50 \mathrm{pM})$, Hpa II $(10 \mathrm{U} / \mu \mathrm{L}), 0.3$ $\mu \mathrm{L} / \mathrm{Msp}$ I (10 U/ $\mu \mathrm{L}), 0.15 \mu \mathrm{L}, 300$ ng DNA, $0.1 \mu \mathrm{L}$ T4 ligase and $\mathrm{ddH}_{2} \mathrm{O}$ (supplemented to $20 \mu \mathrm{L}$ ). The reaction system was kept under the presence of restriction enzymes at $37^{\circ} \mathrm{C}$ for 10 $\mathrm{h}$, at $8^{\circ} \mathrm{C}$ for $4 \mathrm{~h}$, and finally stored at $4^{\circ} \mathrm{C}$ in refrigerator.

Pre-amplification: The reactive solution was evenly mixed as $2.5 \mu \mathrm{L} 10 \times$ PCR reaction buffer, $2 \mu \mathrm{L}$ DNA template (product of enzymatic digestion ligation), $1 \mu \mathrm{L} \mathrm{H} / \mathrm{M}$ adaptor +0 (5 $\mu \mathrm{M}), 1 \mu \mathrm{L}$ EcoR I adaptor $+0(5 \mu \mathrm{M}), 1 \mu \mathrm{L}$ dNTPs $(2.5$ $\mathrm{mM}), 0.2 \mu \mathrm{L}$ Taq DNA polymerase $(5 \mathrm{U} / \mu \mathrm{L})$ and $17.3 \mu \mathrm{L}$ $\mathrm{ddH}_{2} \mathrm{O}$. PCR pre-amplification was conducted according to the following procedure: pre-denaturation at $95^{\circ} \mathrm{C}$ for $2 \mathrm{~min}$ followed by 30 cycles of denaturation at $94^{\circ} \mathrm{C}$ for $30 \mathrm{~s}$, annealing at $56^{\circ} \mathrm{C}$ for $30 \mathrm{~s}$ and elongation at $72^{\circ} \mathrm{C}$ for $60 \mathrm{~s}$. Final elongation was conducted at $72^{\circ} \mathrm{C}$ for 8 mins. Finally, PCR product was electrophoresed on $1.5 \%$ agarose gel for 30 min at $80 \mathrm{~V}$ and $60 \mathrm{~mA}$ voltage and current, respectively. Optimum result was acquired when DNA distributed diffusely within a range from $200 \mathrm{bp}$ to $1000 \mathrm{bp}$. According to the illumination degree of diffused bands, DNA was diluted to $20 \mathrm{ng} / \mu \mathrm{l}$ by adding $\mathrm{ddH}_{2} \mathrm{O}$ and utilized as template for selective amplification.

Selective amplification: The reactive solution was evenly mixed as: $1.5 \mu \mathrm{L} 10 \times$ PCR reaction buffer, $2 \mu \mathrm{L}$ DNA template (diluted product of pre-amplification), $0.6 \mu \mathrm{L} \mathrm{H} / \mathrm{M}$ primer $(5 \mu \mathrm{M}), 0.6 \mu \mathrm{L}$ EcoR I primer $(5 \mu \mathrm{M}), 0.6 \mu \mathrm{L}$ dNTPs (2.5 mM), $0.12 \mu \mathrm{L}$ Taq DNA polymerase $(5 \mathrm{U} / \mu \mathrm{L})$, and 9.85 $\mu \mathrm{L} \mathrm{ddH}_{2} \mathrm{O}$ with a total volume of $15 \mu \mathrm{L}$. PCR selective amplification was conducted according to the following procedure: pre-denaturation at $95^{\circ} \mathrm{C}$ for $2 \mathrm{~min}$, denaturation at $94^{\circ} \mathrm{C}$ for $30 \mathrm{~s}$, annealing at $65^{\circ} \mathrm{C}$ for $30 \mathrm{~s}$, and elongation at $72^{\circ} \mathrm{C}$ for $80 \mathrm{~s}$. Annealing temperature was set to decrease by $1^{\circ} \mathrm{C}$ after each cycle for 10 cycles. Remaining PCR cycle's parameters were: denaturation at $95^{\circ} \mathrm{C}$ for $30 \mathrm{~s}$, annealing at $55^{\circ} \mathrm{C}$ for $30 \mathrm{~s}$ and elongation at $72^{\circ} \mathrm{C}$ for $80 \mathrm{~s}$ which was conducted for 25 cycles. Final elongation was performed at $72^{\circ} \mathrm{C}$ for $8 \mathrm{~min}$.

Table 1. MSAP adaptor sequences used in the analysis, the pre-selective amplification primer sequence and amplification primer sequence composition.

\begin{tabular}{|c|c|}
\hline \multicolumn{2}{|l|}{ Adaptors } \\
\hline \multicolumn{2}{|r|}{ 5'-CACGTAGACTGCGTACC-3' } \\
\hline \multicolumn{2}{|c|}{ EcoR I - adaptor II } \\
\hline \multicolumn{2}{|c|}{$\mathrm{H} / \mathrm{M}$ adaptor $\mathrm{I}$} \\
\hline \multicolumn{2}{|c|}{$\mathrm{H} / \mathrm{M}$ adaptor II } \\
\hline \multicolumn{2}{|c|}{ Primers for pre-amplification } \\
\hline E-0 & 5'-GACTGCGTACCAATTC-3' \\
\hline $\mathrm{H} / \mathrm{M}-0$ & 5'-ATCATGAGTCCTGCTCGG-3' \\
\hline \multicolumn{2}{|c|}{ Primers for selective amplification } \\
\hline \multicolumn{2}{|c|}{ H/M primers } \\
\hline 1.H/M-TTA & 5'-ATCATGAGTCCTGCTCGGTTA-3' \\
\hline 2.H/M-TTG & 5'-ATCATGAGTCCTGCTCGGTTG-3' \\
\hline 3.H/M-TTC & 5'-ATCATGAGTCCTGCTCGGTTC-3' \\
\hline 4.H/M-TCT & 5'-ATCATGAGTCCTGCTCGGTCT-3' \\
\hline 5.H/M-TCC & 5'-ATCATGAGTCCTGCTCGGTCC-3' \\
\hline \multicolumn{2}{|l|}{ EcoR I primers } \\
\hline 1.E-CAC & 5'-GACTGCGTACCAATTCCAC-3' \\
\hline 2.E-TAA & 5'-GACTGCGTACCAATTCTAA-3' \\
\hline 3.E-TAC & 5'-GACTGCGTACCAATTCTAC-3' \\
\hline 4.E-CAA & 5'-GACTGCGTACCAATTCCAA-3' \\
\hline 5.E-GAA & 5'-GACTGCGTACCAATTCGAA-3' \\
\hline 6.E-AAC & 5'-GACTGCGTACCAATTCAAC-3' \\
\hline 7.E-AAA & 5'-GACTGCGTACCAATTCAAA-3' \\
\hline
\end{tabular}

Note: The random combinations of EcoR I primers and $\mathrm{H} / \mathrm{M}$ primers used in selective amplification 
Polyacrylamide gel electrophoresis: A $6 \%$ polyacrylamide gel was prepared from a solution containing $4.5 \mathrm{~mL} 40 \%$ polyacrylamide gel stock solution (Acrylamide/Bis 19:1), 3 mL 10× TBE, $22.5 \mathrm{~mL} \mathrm{ddH}_{2} \mathrm{O}, 140 \mu \mathrm{L} 10 \%$ APS, and $35 \mu \mathrm{L}$ TEMED.

Silver staining: Silver staining detection was conducted according to the following procedure described by Bassam et al. (1991): (1) fixation, the samples were fixed for $5 \mathrm{~min}$ into fixation solution $(150 \mathrm{~mL}$ absolute ethanol, $7.5 \mathrm{~mL}$ glacial acetic acid, and $1500 \mathrm{~mL}$ water); (2) silver staining, the fixed samples were silver-stained for $8 \mathrm{~min}$ in silver staining solution (2.5 $\mathrm{g} \mathrm{AgNO}_{3}, 2.5 \mathrm{~mL}$ formaldehyde and $1500 \mathrm{~mL}$ water); (3) rinsing, the silver-stained samples were placed into 1.5 L water and rinsed 7-8 times (less than $10 \mathrm{~s}$ for each time); (4) development, the rinsed samples were placed into developer (containing $22.5 \mathrm{~g} \mathrm{NaOH}, 3 \mathrm{~mL}$ formaldehyde and $1500 \mathrm{~mL}$ water) for $10 \mathrm{~min}$, until the bands were clearly seen; (5) termination, the developed samples were fixed into fixation solution for $3 \mathrm{~min}$, and then cleaned with water; (6) dehydration, gel plates were placed at room temperature for natural dehydration, then observed and recorded. During the above-mentioned process, shaking was implemented so as to make the samples evenly mixed into the solution.

Data analysis: A FS-Scanner (manufactured by Maxwell Company, USA) was used to record and analyze DNA methylation. On the gel plate, a specific site with a band was marked as " 1 " and a site without a band was marked as " 0 ". When a certain site was cut by Msp I while could not be cut by Hpa II, the gels exhibited Msp I bands without Hpa II bands (marked as "0, 1"), which indicated that the inside cytosine was methylated (CG methylation). When a certain site was cut by Hpa II while could not be cut by Msp I, the gels exhibited Hpa II bands without Msp I bands (marked as "1, 0"), which indicated that the outside cytosine was semimethylated (CHG semi-methylation). When a certain site was cut by both enzymes, both bands appeared (marked as “1, 1"), which indicated no methylation. When a certain site was not cut by these enzymes, no bands appeared (marked as " 0,0 "), which indicated that both inside and outside cytosine of sequence 5'-CCGG-3' were methylated.

\section{RESULTS}

Tomato grafting: The optimum temperatures for grafting ranges $20-25^{\circ} \mathrm{C}$ and relatively higher temperatures are likely to cause infections in wounded branches. Grafting can be optimally conducted in the shade, and dark conditions can promote the growth of callus. However, with green branch grafting, moderate illumination promotes the production of assimilation products and is beneficial for wounded branches. The extra surfaces of scion and stock at grafted position were cut flatly and neatly immediately with sharp tools.

The results of graft were photographed and illustrated in Fig. 1. Figure 1 clearly depicts that the wounded branches healed well and grew rapidly under suitable illumination and optimal temperature conditions. Therefore, the operation of graft met the desired expectations.

Total DNA detection and pre-amplification: Total DNA can be obviously seen that exhibited relatively good complexity, which ranged around 20000 bp size (Fig. 2). Preamplification exhibited that DNA distributed diffusely within a size range of 200-1000 bp (Fig. 3). Therefore, a relatively satisfied effect of amplification was realized.

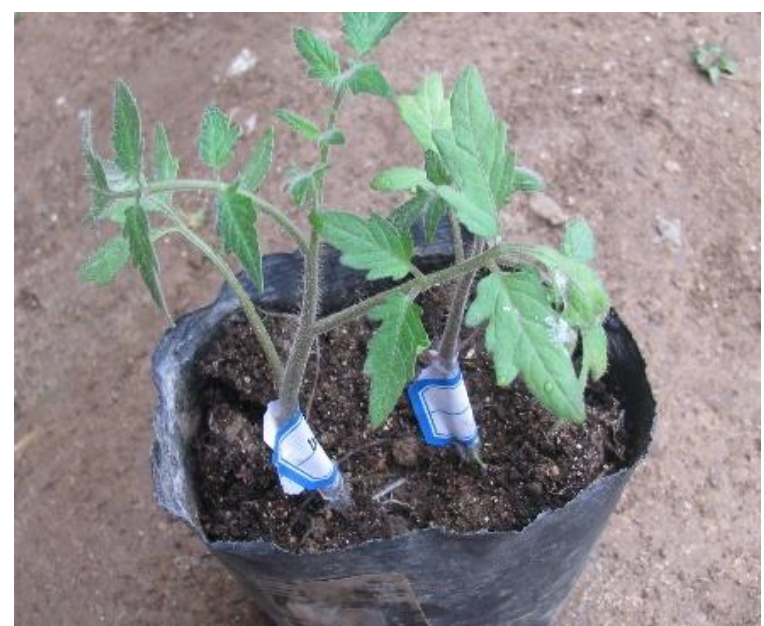

Figure 1. Schematic illustration of grafted tomato. Normal seedling of MM (seedling to the left) grew well under weak illumination, whereas the grafted scion (seedling to the right) grew even better (with bigger leaves and more robust sticks) under weak light radiation, demonstrating enhancement in growth after grafting.

MSAP analysis: Degree of DNA methylation was shown in Figure 4 and Table 2. In this experiment, the types of DNA bands produced were analyzed according to the sensitivities of two kinds of isoschizomers as Msp I and Hpa II to cytosine of sequence 5'-CCGG-3'. Differential display of no methylation, $\mathrm{CG}$ methylation, $\mathrm{CHG}$ semi-methylation and whole methylation is evident from Figure 4. For example, One band is present in un-grafted scion Money Maker (US) treated with Hpa II (lane 4) while absent in US treated with Msp I (lane 1, Fig. 4), which represented semi methylation of outside cytosine or $\mathrm{CHG}$ semi-methylation. One band is

Table 2. Degree of cytosine methylation of grafted plants (scion) and control plants.

\begin{tabular}{lcccc}
\hline Cultivar/MD & No Methylation & CG Methylation & CHG semi-methylation & Whole Methylation \\
\hline Cultivar MM & $4(11.4 \%)$ & $15(42.9 \%)$ & $7(20.0 \%)$ & $9(25.7 \%)$ \\
Scion MM (Grafted) & $6(17.1 \%)$ & $11(31.4 \%)$ & $10(28.6 \%)$ & $8(22.9 \%)$ \\
Cultivar 1221 & $6(17.1 \%)$ & $7(20.0 \%)$ & $14(40.0 \%)$ & $8(22.9 \%)$ \\
\hline
\end{tabular}

Note: "MD" refers to "Methylation Degree". 
present in graft hybrid (GF) treated with Msp I (lane 2) while absent in GF treated with Hpa II (lane 5), which represented methylation of inside cytosine or CG methylation. In contrast, one band is present in GF (lane 5) treated with Hpa II while absent in GF treated with Msp I (lane 2), which represented semi methylation of outside cytosine or CHG semimethylation. Two bands are present in un-grafted rootstock 1221 (UR) treated with Msp I (lane 3) compared to UR treated with Hpa II (lane 6), which represented methylation of inside cytosine or CG methylation.

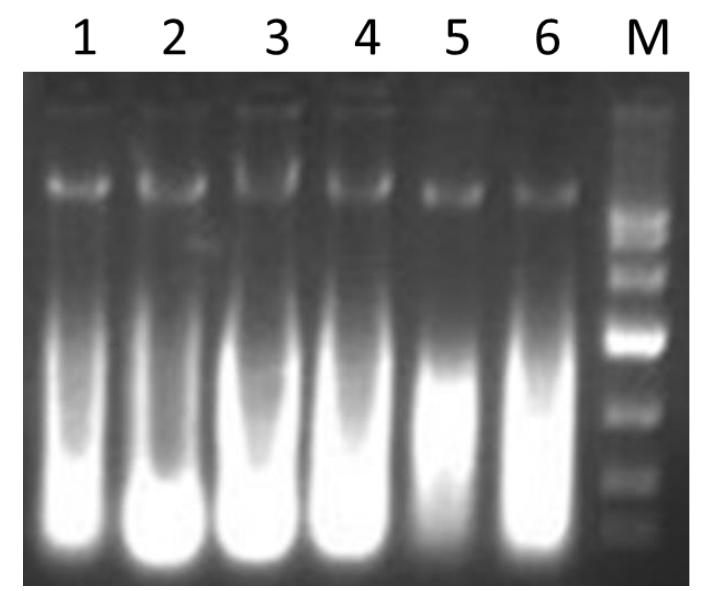

Figure 2. Total DNA of un-grafted 1221 tomato root stock used for MSAP analysis showing relatively good completeness around 20000 bp size. Lane $M$ represents marker bands of 15000, 10000, 7500, $5000,2500,1000,250$ bp from top to bottom, respectively.

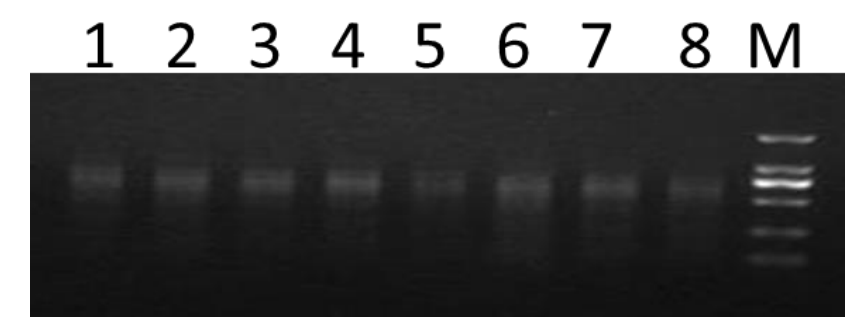

Figure 3. Pre-amplification electrophoresis pattern ungrafted 1221 tomato rootstock used for MSAP analysis. Before DNA amplification, target DNA concerning MSAP adaptor sequences was extracted and purified for further analysis and amplification. Pre-amplification exhibited that DNA distributed diffusely within a size range of 200-1000 bp, and a relatively satisfied effect of amplification was realized. Lane $\mathrm{M}$ represents $2 \mathrm{~Kb}$ DNA ladder showing band sizes of 2000, 1000, 750, 500, 250 and $100 \mathrm{bp}$ from top to bottom, respectively.

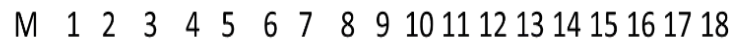

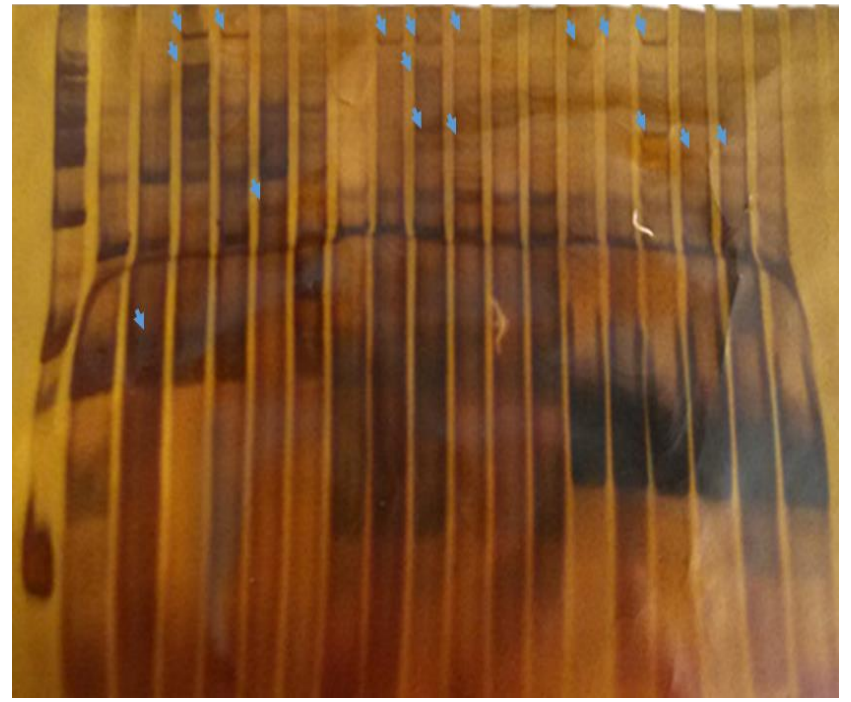

Figure 4. MSAP analysis of tomato un-grafted scion Money Maker (US), graft hybrid (GH) and ungrafted rootstock 1221 (UR). Lane $M$ represents marker bands of 15000, 10000, 7500, 5000, 2500, 1000, 250 bp from top to bottom respectively. Respective lanes of US, GH and UG samples treated with; Msp I-TTA + EcoR I-CAC (lane 1-3), Hpa II-TTA + EcoR I-CAC (lane 4-6), Msp I -TTG + EcoR I-CAC (lane 7-9), Hpa II-TTG + EcoR ICAC (lane 10-12), Msp I-TTC + EcoR I-CAC (lane 13-15) and Hpa II-TTC + EcoR I-CAC (lane 1618). Lanes 1-6, 7-12 and 13-18 belong to different comparison groups. Comparisons were conducted between lanes 1 and 4, 2 and 5, 3 and 6, 7 and 10,8 and 11,9 and 12,13 and 16, 14 and 17, and 15 and 18 , respectively. For example, comparison between lanes 2 and 5 shows presence of a band in lane 5 but not in the same position of lane 2 indicating that some points in DNA were splitted by Hpa II but Msp I could not split. This point is marked as $(1,0)$ showing the semi-methylation of outside cytosine of $\mathrm{CHG}$ sequence, which means possible improvements in disease-resistance or weak-light tolerance in lane 5 compared to lane 2.

From Table 2, it can be obviously seen that degree of DNA methylation changes after grafting. Degree of DNA methylation of "scion MM" (grafted) in sequence 5'-CCGG3 ' showed a tendency of general decline, degree of inside cytosine methylation (CG methylation) dropped most significantly to $31.4 \%$ compared to check cultivar MM (42.9\%), degree of $\mathrm{CHG}$ semi-methylation enhanced to $28.6 \%$ from $20 \%$ and degree of whole methylation declined to certain extent ( $22.9 \%$ from $25.7 \%)$. 


\section{DISCUSSION}

Plant grafting has been widely applied as a reproductive technology of asexual cloning into the proliferation of fruiting trees, flowers and vegetables (Shao et al., 2005; Wang et al., 2009). Therefore, in recent years, the technologies and theories concerning plant grafts have gained more and more importance. Grafting can not only give rise to phenotypic variations, but also create inheritable variations (Keiko et al., 2007; Li et al., 2013; Wu et al., 2013), and variation in cellular environments. . It was found in many studies that the alterations of cellular environment can readily cause changes in DNA methylation leading to the variations in biological traits of organisms. Currently, although many studies have been conducted on the changes in the physiological indices of grafted tomatoes under a myriad of adverse biotic and abiotic stresses (Cockshull, 1992; Mukherjee et al., 2010). Studies related to variations in the connective joints of grafting have been extensively conducted, further research at molecular level to investigate DNA methylation have been relatively less frequent. Therefore, such aspects of grafting represent a prospecting domain in the future. In this research, we conducted primary research on the alterations in DNA methylation of grafted tomato.

The degree of DNA methylation varied to certain extents in cultivar MM, which was used as scion for graft hybrid. The highest rate of CG methylation amounted to $42.9 \%$ and the lowest rate of no methylation was $11.4 \%$ (Table 2, Fig. 4). In contrast, degree of methylation in rootstock cultivar 1221 showed highest rate of CHG semi-methylation (40\%, Table 2). In graft hybrid, scion MM (grafted) showed decrease in $\mathrm{CG}$ methylation and increase in CHG semi-methylation and approach to respective values of 31.4 and $28.6 \%$, which is equal to average $\mathrm{CG}$ methylation and $\mathrm{CHG}$ semi-methylation responses of two check cultivars respectively. The degree of methylation after the grafting of disease-sensitive cultivar "MM" (which is low light stress tolerant too) to diseaseresistant cultivar " 1221 " altered, the former as scion began to change and approached approximately middle of the expression of two check cultivars, which might result in gene expression changes in tomato cultivars and affect the alteration of phenotypic traits. A recent study reported that hetero-grafting altered DNA methylation patterns extensively in a locus-specific manner, especially in scions, although relative methylation levels remain largely unaltered $(\mathrm{Wu}$ et al., 2013). Further, the altered methylation patterns in the hetero-grafting-derived scions could be inherited to sexual progenies with some sites showing further alterations or revisions and caused dynamic changes in steady-state transcript abundance of genes encoding for a set of enzymes functionally relevant to DNA methylation. Consequently, it can be inferred that graft hybrid will change its response to stress. Graft hybrid in the present studies was vigorous and showed better performance to low light stress as compared to check cultivar MM (Fig. 1). It has been reported in many research studies that some physiological indices changed after grafting (Afshari et al., 2011; Jang et al., 2011).

Comparisons between lanes of grafted materials i.e., lanes 2 and 5, lanes 8 and 11, and lanes 14 and 17 indicated improvements in disease-resistance or weak-light tolerance (Fig. 4). Lane 5 showed increased disease-resistance in comparison with lane 2, lane 11 exhibited improved weaklight tolerance in comparison with lane 8, and lane 17 possessed both enhanced disease-resistance and weak-light tolerance in comparison with lane 14 . However, comparisons between lanes of un-grafted materials showed no obvious improvements in disease-resistance or weak-light tolerance. It is concluded that graft hybrid tomatoes changed DNA methylation pattern which might led to changes in gene expression and regulation in order to adapt it to the environmental adverse conditions. Such alterations might resulted in the improved phenotype and performance of graft hybrid to low light stress. However, detailed information concerning the molecular mechanism of these responses still needs to be further clarified.

Acknowledgement: This research was jointly supported by Henan Province Science and Technology Development Project (Grant No. 082102140018; 102300410034), National Natural Foundation of China (Grant No. 31000744), Jiangsu Autonomous Innovation of Agricultural Science \& Technology [CX(15)1005], and the CAS/SAFEA International Partnership Program for Creative Research Teams. Thanks were also extended to the referees for their conductive comments.

\section{REFERENCES}

Ahmad, A., S. Shafique and S. Shafique. 2014. Molecular basis of antifungal resistance in tomato varieties. Pak. J. Agri. Sci.51: 685-689.

Afshari, R.T., R. Fngoshtari and S. Kalantari. 2011. Effect of light and different plant growth regulators on induction of callus growth in rapeseed (Brassica napus L) genotypes. Plant Omics J. 4:60-67.

Bassam, B.J., G. Caetano-Anollés and P.M. Gresshoff. 1991. Fast and sensitive silver staining of DNA in polyacrylamide gels. Anal. Biochem. 196: 80-83.

Benard, C., H. Gautier, F. Bourgaud, D. Grasselly, B. Navez, C.C. Veyrat, M. Weiss and M. Genard. 2009. Effects of low nitrogen supply on tomato (Solanum lycopersicum L.) fruit yield and quality with special emphasis on sugars, acids, ascorbate, carotenoids, and phenolic compounds. J. Agri. Food Chem. 57:4112-4123.

Cao, X., W. Aufsatz, D. Zilberman, M.F. Mette, M.S. Huang, M. Matzke and S.E. Jacobsen. 2003. Role of the DRM and CMT3 methyltransferases in RNA directed DNA methylation. Current Biol. 13:2212-2217. 
Chen, Z.J and C.S. Pikaard. 1997. Epigenetic silencing of RNA polymerase I transcription: A role for DNA methylation and histone modification in nucleolar dominance. Genes Dev. 11:2124-2136.

Cockshull, K. 1992. Shading on yield of glasshouse tomatoes. J. Hortic. Sci. 67:11-24

Davies, G.J., M.A. Sheikh, O.J. Ratcliffe, J. Coupland and I.J. Furner. 1997. Genetics of homology-dependent gene silencing in Arabidopsis: a role for methylation. Plant J. 12:791-804.

Ding, J.P., X.C. Xu and W.Q. Li. 2015. Physiological changes of tomato after grafting. Northern Hort. 05: 29-31 (In Chinese with an English Abstract).

Flores, F., B.P. Sanchez-Bell and M.T. Estan, 2010. The effectiveness of grafting to improve tomato fruit quality. Hort. Sci. 125: 211-217

Hanson, B.R. and D.M. May. 2006. Crop evapotranspiration of processing tomato in the San Joaquin Valley of California, USA. Irrig. Sci. 24:211-221.

Jang, Y.A., E. Goto, Y. Ishigami, B. Mun and C. Chun. 2011. Effect of light intensity and relative humidity on photosynthesis, growth and graft-take of grafted cucumber seedlings during healing and acclimatization. Horti. Environ. Biotechnol. 52:331-338.

Keiko, O.K., T. Masahide, K. Noya, F. Kazuhiro and K. Kenji. 2007. Effect of light quality on growth and vegetable quality in leaf lettuce, spinach, and komatsuna. Environ. Control Biol. 45:189-198.

Kuscu, H., A. Turhan, N. Ozmen, P. Aydinol and A.O. Demir. 2014. Optimizing levels of water and nitrogen applied through drip irrigation for yield, quality, and water productivity of processing tomato (Solanum lycopersicum L.). Horti. Environ. Biotechnol. 55:103-114.

Lazár, D., P. Sušila and J. Nauš. 2006. Early detection of plant stress from changes in distributions of chlorophyll a fluorescence parameters measured with fluorescence imaging. J. Fluorescence. 16: 173-176

Li, X., S. Zhu, Y. Liu, S. Xue and W. Li. 2013. Multivariate statistical analysis of low-light tolerance in tomato (Solanum lycopersicum L.) cultivars and their ultrastructural observations. J. Plant Growth Regul. 32:646-653.

Mukherjee, A., M. Kundu and S. Sarkar. 2010. Role of irrigation and mulch on yield, evapotranspiration rate and water use pattern of tomato (Solanum lycopersicum L.). Agric. Water Manage. 98:182-189.

Saleem, M.Y., K.P. Akhtar, , Q. Iqbal, M. Asghar, and M. Shoaib. 2015. Development of high yielding and blight resistant hybrids of tomato. Pak. J. Agri. Sci. 52: 293299.
Ozbahce, A. and A.F. Tari. 2010. Effects of different emitter space and water stress on yield and quality of processing tomato under semi-arid climate conditions. Agric. Water Manage. 97:1405-1410.

Patanè, C., S. Tringali and O. Sortino. 2011. Effects of deficit irrigation on biomass, yield, water productivity and fruit quality of processing tomato under semi-arid Mediterranean climate conditions. Hort. Sci. 129:590596.

Qi, H.Y. and C. Li. 2011.Response to different levels of low light stress of two varieties of tomato. Southwest China J. Agri. Sci. 24:523-528 (In Chinese with an English Abstract).

Rahmatian, A, M. Delshad and R. Salehi. 2014. Effect of grafting on growth, yield and fruit quality of single and double stemmed tomato plants grown hydroponically. Hort. Environ. Biotech. 55: 115-119.

Riggi, E., C. Patane and G. Ruberto. 2008. Content of carotenoids at different ripening stages in processing tomato in relation to soil water availability. Aust. J. Agri. Res. 59:348-353.

Shao, H.B., Z.S. Liang and M.A. Shao. 2005. Changes of antioxidative enzymes and MDA content under soil water deficits among 10 wheat (Triticum aestivum L.) genotypes at maturation stage. Colloids Surf. B: Biointerfaces. 45:7-13.

Stitt, M. J., and B.L. Usadel. 2010. Arabidopsis and primary photosynthetic metabolism-more than the icing on the cake. Plant J. 61: 1067-1091

Wang, H., M. Gu, J. Cui, K. Shi, Y. Zhou and J. Yu. 2009. Effects of light quality on $\mathrm{CO}_{2}$ assimilation, chlorophyllfluorescence quenching, expression of Calvin cycle genes and carbohydrate accumulation in Cucumis sativus. J. Photochem. Photobiol. B. 96:30-37.

Wu R. 2009. Study on the variation of DNA methylation patterns and possible mechanisms of the genetic changes of the plants in the family of the grafted plants. [M]. Master Dissertation of Northeast Normal University (In Chinese with an English Abstract)

Wu, H., Y. Qin, C.Y. Lin, S.Y. Tang and W.Y. Yang. 2010. The comparison test between cleft grafting and casing pipe grafting method on Capsicum annuum L. Northern Hort. 34: 40-42 (In Chinese with an English Abstract).

Wu, R., X. Wang, Y. Lin, Y. Ma, G. Liu, X. Yu, S. Zhong and B. Liu. 2013. Inter-species grafting caused extensive and heritable alterations of DNA methylation in Solanaceae plants. PLoS ONE. 8: e61995.

$\mathrm{Yu}, \mathrm{H}$., and B.L. Ong. 2003. Effect of radiation quality on growth and photosynthesis of Acacia mangium seedlings. Photosynthetica. 41: 349-355 